\title{
THE PROCESS OF SPIRITUAL EDUCATION OF YOUTH
}

\author{
Odiljon Rahimjonovich Topildiyev
}

Candidate Of Historical Sciences, Associate Professor, Department Of "Culturology" Namangan State University

\section{ABSTRACT}

The article analyzes such issues as family, neighborhood, educational institutions - a factor of true spiritual education in the spiritual education of young people, issues of interest to them, based on the directions of a systematic approach in studying the impact on the spiritual education of young people of the correct organization of life, employment and free time.

KEYWORDS: - Youth, spiritual education, family, neighborhood, educational institutions, upbringing, influence on the spiritual education of youth, youth employment, proper organization of youth leisure.

\section{INTRODUCTION}

To build an active civil society in Uzbekistan, it is important to activate the activities of young people, increase their political activity and coordinate their actions. Although young people are an important driving force for social development, they are important actors in the socio-political, economic, cultural and spiritual renewal of society and have a positive or negative impact on development and changes in social life. The bright future of Uzbekistan depends on the spiritual and ideological outlook of young people, their activity in social, political and democratic processes.

At this point, the following statement of the President of the Republic of Uzbekistan Sh. M. Mirziyoyev: "In the development of any society, a healthy and harmonious adult life of the younger generation is of decisive importance, ensuring its future. We all need to set great goals for our young people, create wide opportunities for them. to achieve them and provide all-round support. It is important to note that our children will become a great and powerful force that will fulfill the centuries-old dreams of our people" ${ }^{\mathbf{1}}$. It is known that the upbringing of the younger generation has become more important and relevant at all times. But today, where we live, this question really becomes a matter of life.

Consistent and decisive continuation of work on the problem of youth requires special attention to social, political and democratic processes. During 1991-2021, the formation of national statehood in Uzbekistan, the formation of new economic relations and the legal system, youth became a decisive force for development.

In fact, in order to draw attention to the still unresolved problems of young people, who today constitute the bulk of the population, the

1 Ўзбекистон Республикаси Президенти Шавкат Мирзиёевнинг 2020 йил 29 декабрдаги Олий Мажлисга мурожаатномаси // Халқ сўзи, 2020 йил 29 декабрь. 
CURRENT RESEARCH JOURNAL OF HISTORY 2(5): 78-82, May 2021

DOI: https://doi.org/10.37547/history-crjh-02-05-18

ISSN 2767-472X

(C)2021 Master Journals

\section{Crossref dof 81 Google}

Accepted 25th May, 2021 \& Published 31 ${ }^{\text {th }}$ May, 2021

upbringing of a healthy and harmonious generation requires not only the participation of state bodies, educational institutions, but also the participation of the general public. The solution of this important strategic task today in many respects requires joint fruitful work of the family, neighbors, educational institutions and civil society institutions. People involved in the upbringing of the younger generation, that is, in the family - parents, in the neighborhood - Aries and the general public, in the educational institution - teachers and mentors are responsible for the well-being of the future generation, so that young people are worthy of our glory. In this sense, the family, neighborhood, educational institutions are the environment of true spiritual education, the first concepts characteristic of national education are respect for adults, respect for little ones, humanity, compassion, loyalty to their homeland, people, such noble qualities are formed in the environment as family, neighborhood and educational institutions.

If we can form a healthy spirit and a high spiritual outlook in young people from childhood, they will grow up to be educated, independent and harmonious people. Because young people belong to such a social group of society that they have acute emotional and cognitive abilities and more strongly feel cases of inconsistency of practice with the word. Some cases, typical for adults, can strongly affect the not yet fully formed consciousness, worldview of young people. Therefore, it is necessary to refrain from telling the truth to young people, to avoid forgery, to openly declare existing problems. But some parents transfer the upbringing of their children to educational institutions or society, are not interested in the fate of their son-daughter, are apathetic that they "see a breakdown in the forehead".

Also, the factors that negatively affect the behavior, spiritual education of modern youth are mainly the following:

- Mass media of various illusory, pornographic content (films on disks, clips, photos on mobile phones, etc.), which penetrate the Internet, carry spiritual threats to young people;

- increased interest in "mass culture" among young people and disinformation spread from the Internet;

- unhealthy lifestyle (alcoholism, drug addiction, etc.));

- computer games based on violence;

- low educational level of parents;

- uncontrolled and neglected (social orphans));

- low interest in education;

- excessive manipulation of the child by the parent;

- conflicts arising from material problems;

- inability to notice changes in the child, indifference and indifference;

- passing free time.

From the above, it is clear that in order for young people to grow up spiritually mature and physically healthy, it is necessary to eliminate the factors that negatively affect them. This, in turn, requires responsibility and dedication on the part of the family, society, educational institutions, law enforcement agencies, government and non-governmental organizations, and every citizen in general. In this regard, the main task of the family, society and educational institution is the upbringing of harmoniously developed youth in accordance with the needs of society. The patriotism of youth begins with the spiritual environment in family education, neighborhood and educational institutions, it is difficult for a person who does not value his family, neighborhood and 
educational institution to evaluate his homeland. The family, community and educational environment play a leading role in shaping the spirituality of young people. Today it is important to provide an integrated, systematic approach to educational work, which requires the integrity of all spheres and areas of education.

The directions of an integrated systematic approach to studying the impact on youth education can be seen in the following:

1. Types of education - physical education, moral education, labor education, spiritual education.

2. Teaching methods - individual method, collective method, mass method.

3. Means of education - science, education, culture, literature, art, press, radio, television, theater, cinema, information technology, the Internet.

4. Factors of upbringing - family, school, neighborhood, social environment.

5. Study process - time before study, study time, working time, free time after work.

Thus, when studying the influence on the spiritual education of young people, it is important, on the basis of a systematic approach, to solve issues of interest to them, such as life desires, employment and the correct organization of leisure. This, in turn, testifies to the need to pay special attention to the development of cooperation between the family, society and educational institutions in order to increase the effectiveness of the spiritual education of young people.

In this regard, the President of the Republic of Uzbekistan Sh.M. Mirziyoyev stressed the need for large-scale reforms based on the idea that "the new Uzbekistan starts from the threshold of the school, the education system."
As a result, first of all, to provide quality education to the younger generation in kindergartens, schools and universities, to mobilize all efforts and opportunities so that they grow up physically and spiritually healthy, patriotic people;

Secondly, to educate young people as people who think independently and logically on the basis of modern knowledge and experience, national and universal values and possessing good qualities;

Thirdly, to train our boys and girls in modern professions that are in great demand in the labor market, to form their entrepreneurial skills and hard work, to give priority to the implementation of their initiatives, employment and housing.

In short, from the moment a child is born until the age of 30 , he is determined to create a holistic and continuous system that supports him in all respects, helping him find a worthy place in life.

Based on the above, taking into account the future fate and prospects of youth, in today's era of globalization, it is advisable to make the following proposals to increase the effectiveness of spiritual education of the young, harmoniously developed generation:

1. Improving the activities of state and non-state organizations involved in youth activities, social movements, making the most of their opportunities.

2. To organize regular appearances and events on television, radio and in the media with the aim of further reviving spiritual, educational and ideological work related to youth activities, and to coordinate all work in this area, to widely promote the traditions and customs that establish an example for young people in the community.

3. Further strengthening of the activities of specialists directly involved in spirituality in schools, lyceums, colleges and universities, as well as the organization of the "Parents' Day" 
once a month or every three months, the development of the national foundations of spiritual and educational work in Russia. educational institutions. It is also necessary to establish an "open door for dialogue" to increase cooperation between families, communities and educational institutions in the implementation of youth control. Attracting students who chronically do not enter educational institutions with the help of educational institutions, social activists and the Cooperation Council, chronic and individual work with difficult youth, parents who neglect the upbringing of their children, the systematic organization of pedagogical counseling.

4. Creation of psychological centers for the continuous study of the lifestyle, psyche and interests of young people and their work on the basis of a special plan, program.

5. Critical analysis of the educational value of films, cartoons, videos, songs, pictures promoting "mass culture" with the participation of young people and the formation of a culture of ideological immunity, information consumption among young people.

6. In the process of promoting national values among young people, take into account the peculiarities of youth and form a sense of hard work, discipline, and responsibility.

7. Creation of conditions for the effective organization of youth leisure, wide involvement in useful activities and the development of various scientific and sports clubs.

8. In order to strengthen the principles of a healthy lifestyle among young people, to protect them from the threats of alcoholism, drug addiction, immorality, mass culture, to constantly explain the dangers of terrorism, religious fanaticism, missionary work among young people in the neighborhood. and educational institutions.
9. Systematic and purposeful organization of advocacy work in the community to prepare young people for family life. Support young people in need of social protection, young families and improve their health literacy.

10. Measures aimed at increasing the legal, spiritual, moral, psychological, pedagogical and physiological knowledge of parents on the upbringing of a harmoniously developed young generation, conducting seminars and trainings in cooperation with communities, educational institutions and providing the necessary consultations.

11. Social activity of young people in the family, in society, independent work, striving for innovation, support for entrepreneurship and the creation of additional opportunities for youth entrepreneurship.

12. Introduce into the system of citizens' selfgovernment bodies the position "Youth Leader" on working with unorganized youth in microdistricts.

13. For the upbringing of a healthy generation, it is necessary to form ecological education in the family from childhood, to conduct educational activities in cooperation with communities and educational institutions, to study and popularize the experience of exemplary families.

In conclusion, educational work, carried out in various ways, plays an important role in the education of physically healthy, spiritually mature youth. Indeed, in the new millennium, the fate of states and peoples will be decided not by material wealth, but by young people with mature intellectual potential and high spirituality. That is why today we have set ourselves a great goal - to lay the foundations of the Third Renaissance in our country, for which we must create an environment and conditions that will bring up new Khorezmш, Beruni, Ibn Sino, Mirzo Ulugbek, Navoi and Babur. In this 
regard, first of all, the development of education and upbringing, decisions on a healthy lifestyle, the development of science and innovation should play an important role.

\section{REFERENCES}

1. Farfieva K. A. Social Media as a factor in formation of scientific thinking in youth. European Journal of Research and Reflection in Educational Sciences. Vol. 8 No. 10, 2020. Pp. 52-56.

2. Farfieva, K. A. (2021). Theoretical Fundamentals of Scientific And Innovative Thinking In Adolescents. The American Journal of Social Science and Education Innovations, 3(04), 431-437.

3. Adiba Ergashevna Shaymanova. (2020). THE CLASS OF THE MIDDLE PROPRIETORS - THE GUARANTEE OF THE DEVELOPMENT AND SUSTAINABILITY OF THE CIVIL SOCIETY. Journal of Central Asian Social Studies, 1(01), 95-105.

https://doi.org/10.37547/jcass/volume01 is sue01-a10

4. Shomirzayev, M. (2020). Developing Educational Technologies In School Technology Education. The American Journal of Engineering and Technology, 2(07), 51-57. https://doi.org/10.37547/tajet/Volume02Is sue07-08

5. Atxamdjanovna, F. K. (2020, December). Effectiveness of physical culture education effects of adolescents on scientific thinking in growth location of effective information. In Конференции. 